\title{
Emerging Public Health Concern and Air Pollution: A Case Study of Delhi's Air Pollution Governance
}

\author{
Dr. Subhadra Rajpoot ${ }^{1}$ | Devang Pratap Singh ${ }^{2}$ \\ ${ }^{1}$ Department of Applied Sciences, Amity School Of Engineering and Technology, Greater Noida, India. \\ ${ }^{2}$ Student of Computer Science and Engineering. Amity School of Engineering and Technology, Greater Noida, India
}

\section{To Cite this Article}

Dr. Subhadra Rajpoot and Devang Pratap Singh, "Emerging Public Health Concern and Air Pollution: A Case Study of Delhi's Air Pollution Governance", International Journal for Modern Trends in Science and Technology, Vol. 06, Issue 05, May 2020, pp.: 196-201; https://doi.org/10.46501/IJMTST060530

\section{Article Info}

Received on 29-April-2020, Revised on 15-May-2020, Accepted on 20-May-2020, Published on 26-May-2020.

\section{ABSTRACT}

Air Pollution is a major concern in today's scenarios as it is leading to serious health hazards and also retrograding our environment. In recent times there has been a rapid increase in various health factors which has affected lives at a very vast scale. Talking about air pollution in cities like Delhi and other metro cities where air pollution is at its peak. Talking about Delhi which is sometimes also referred as 'Gas Chamber' has been a research model for managing risk and controlling air pollution in mounting and towards making Delhi's environment healthy. In this research paper we are trying to understand air pollution governance as a means of risk management. Delhi which follows multi-level governance where public health emergencies in recent times, keeping public trust doctrine as the conceptual basis to look at governance. Delhi traversing as National Capital Territory can be considered as a victim of the Air Pollution and its consequent impacts. The lack of integrated approach in Delhi for risk governance has made this process multifaceted and a challenging task. This study can enlighten us on emergence of public health concerns due to air pollution and its governance, keeping in consideration it has not kept an equal balance even with the backing of legislative measures and intervention of court laws. Due to increasing air pollution levels in the city, right to Life and right to a Healthy Environment are being violated from which the levels of air quality continues to be poor. Lastly for which good governance is required in order to reduce the same at this pandemic.

KEYWORDS: Air pollution, Public Health, Delhi, Air quality, Gas Chamber, Healthy Environment, Governance.

Copyright (C) 2014-2020 International Journal for Modern Trends in Science and Technology, All rights reserved. DOI: https://doi.org/10.46501/IJMTST060530

\section{INTRODUCTION}

An Overview to Emerging Air Pollution and Delhi's case Healthy environment and pure air is always a pre-necessity for the wellness of people. In the renovating world, metropolitan extension and industrial development has been a speedy process. Due to industrial expansion and rapid modernization, pure air in cities has become an unusual occurrence.

1. However, Air Pollution in India and the World has become an environmental health hazard over the years. Because of exposure to polluted air people are at risk of several kinds, health risk is the most important one of them. 
According to a report by World Health Organization (WHO), around 7 million people lose their life every year prematurely as a result of worldwide air pollution.

2. Meanwhile the world in present time wishes to achieve stability, Delhi's unstable and declining air quality is again under scrutiny. India is a signatory to the Sustainable Development Goals. Goal three which calls for promoting good health and has Indicators directly linked to air pollution and health risks; and Goal eleven is to make cities and human settlements inclusive, safe and resilient, which lists a specific indicator to reduce the environmental impacts of cities which including reduction of particulate levels in the air.

3. Air Pollution in India has become an issue of national importance. Air quality in many urban and rural places in India is very poor. Delhi, being India's capital is top in the red list. Regarding air pollution Delhi has also been a frequent part of Central Pollution Control's list of Non-attainment cities list with respect to ambient air pollution. This paper is rotted on the research conducted upon Delhi's case of air pollution. 4

Delhi is a union territory and a sub-state; the federal complications of air pollution risk governance have become a difficult task. Since there is an underlined interface between the public health concern and this health risk regime. Here risk management is very important and hence governance comes into this picture which has become important for this study. Air pollution in Delhi is not an extant cause of worry but has been now remarkable for long by several agencies. Again various policy dynamics have been introduced by different governments and authorities to save Delhi's Air. This paper tries to explore the development and structure of this governance process through its various sections and analyze. Finally, various issues of concern to the air pollution regime in Delhi have been identified and some suggestions have been circumvented.

\section{HEAlth Risk AND AIR POLlUtion}

The air that the whole world breathes today include various amounts of hazardous gases like as particulate matter (PM2.5, PM10), ozone (O3), Sulphur dioxide (SO2) and Nitrogen Oxide (NO2). Urban areas today experiences high air pollution levels, which has been affecting the human health adversely. With each breath that goes inside the lungs, people are placed at an inevitable health risk. While due to the presence of these toxic pollutants in the air, the air is getting polluted adversely. These gases and the polluted air is proving to be not only harmful to health but also fatal for human life as well.

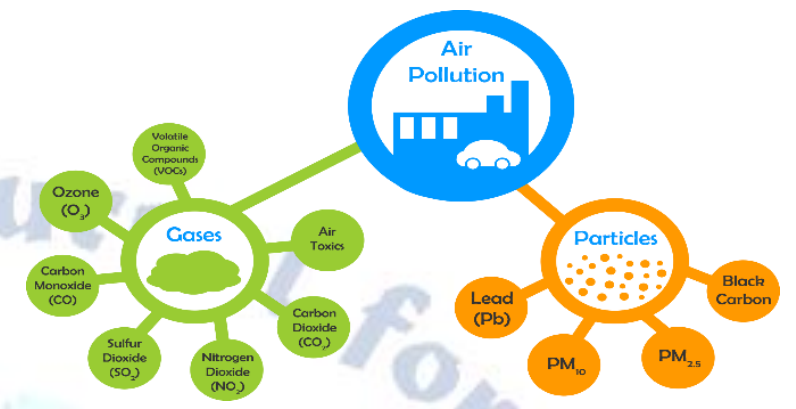

Figure 1: Gases and Particles Present in Air Pollution.

Air pollution has been manifestly recognized as direct menace to public health throughout the world. According to a State of global air 2017 report, the number of deaths has been increased with the increase in the level of pollutants. 6 The exposure to PM2.5 has been leading to the environmental risk factors attributing to deaths and has accounted for about 4.2 million deaths and ranks fifth among all risks worldwide. The aforesaid report observes that China and India together account for $52 \%$ of the total global deaths due to PM2.5.

From the complete review of diverse scientific and health related studies, it has been found that there have been some impacts on the people who are exposed to air pollution. Health impacts however may vary for short term and long-term exposure. the health impacts have been found ranging from cardiovascular diseases, strokes, respiratory diseases, and lower respiratory infections (LRIS), chronic obstructive pulmonary disease (COPD) in the short run; and impacts on brain, lung cancer, other heart diseases and reduction in life expectancy as anticipated consequences of long-term exposure to the polluted air.

Outdoor pollution is always considered as the most big sort of pollution but indoor air pollution has also appeared as one of the major sources of origin of pollution and a point of high exposure entirely. 'Dual exposure' to ambient (outdoor) and household(indoor) pollution has been observed as more hazardous as it puts people at increased exposure increasing their health risk directly. 


\section{The Demonstration OF DELHI'S AIR}

'The air quality in Delhi is the most affected capital territory in the world', said WHO in 2014 to which India denied. Though, it is a serious contemporary issue as the pollution levels have increased in Delhi to an extent from 2017.Indian Medical Association declared Delhi as Public Health Emergency with Delhi government directing shut down of industries and closing down of schools.

The record says, Delhi's situation hasn't come under control but has rather increased manifold from late 1980's to till date.

\section{Sources of Emissions of Air Pollutants}

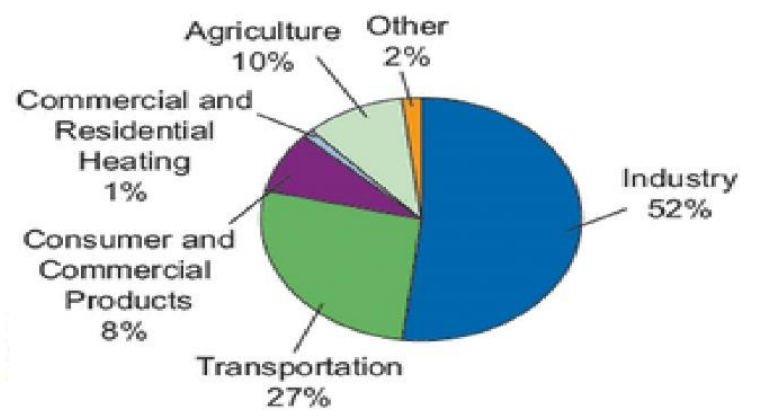

Figure 2 : Sources Of Emissions of Air Pollution.

This is evident from the fact that in Delhi, between the years 1991-94, the average total suspended particulate matter (SPM) levels in Delhi was 375 micrograms per cubic meter $(\mu \mathrm{g} / \mathrm{m} 3)$ which was approximately 5 times high than the Air Quality Guidelines (AQG) by WHO. Today, levels of Particulate Matter have been observed to have overshot the WHO standards. As per the present WHO mandates the levels of PM2, should be $10 \mu \mathrm{g} / \mathrm{m} 3$ annually but in Delhi it reached up to $120 \mu \mathrm{g} / \mathrm{m} 3$ for 2016 . Levels as per WHO standards should be $20 \mu \mathrm{g} / \mathrm{m} 3$ annually but it in Delhi reached up to $300 \mu \mathrm{g} / \mathrm{m} 3$ for 2016.11 It should also be noted here that the statistical levels of pollutants presented above for 2016 are also overshooting the national parameters set as Air Quality Index by CPCB.

Delhi pollution is directly related to sources which are contributing in making the air polluted , the different set of reasons includes the emission source, Delhi's geographic location, its climatic conditions and temperature, and its concrete urban space with expanding urban sprawl makes it a hotspot of pollution hence named as 'Gas Chamber'. The issue is of grave concern as it directly impacts people's health. According to a study conducted in Delhi (1991-94). Air Pollution is statistically significant determinant of daily deaths for all categories of deaths. India has the world's highest death rate from chronic respiratory disease and asthma, according to the WHO. In Delhi, poor quality air irreversibly damages the lungs of 2.2 million or 50 percent of all children.

Factor of animal agriculture, as smog and other Delhi's pollution problem is also caused by the harmful particles are produced by farmers burning their crops in other states About 80 percent of agriculturally used land is used for animal agriculture, so animal agriculture can also be attributed as a factor in Delhi's air pollution problem. The reduction in life expectancy and trend of deteriorating health conditions are evidently presenting deadliness of air and dangers associated with the sustainability of life in Delhi as it has now become a serious and critical crisis to control on.

List of major contributors to the air pollution in Delhi:

\begin{tabular}{|c|c|c|}
\hline $\begin{array}{l}\text { Mobile } \\
\text { Sources }\end{array}$ & $\begin{array}{l}\text { Stationary } \\
\text { Sources }\end{array}$ & $\begin{array}{l}\text { Indoor } \\
\text { Sources }\end{array}$ \\
\hline $\begin{array}{l}\text { Vehicular } \\
\text { Pollution }\end{array}$ & $\begin{array}{l}\text { Burning of } \\
\text { stubbles by } \\
\text { farmers (in nearby } \\
\text { states of Haryana } \\
\text { and Punjab) }\end{array}$ & $\begin{array}{l}\text { Combustion } \\
\text { of cooking } \\
\text { fuels }\end{array}$ \\
\hline $\begin{array}{l}\text { Re-suspension } \\
\text { of dust and } \\
\text { another } \\
\text { fugitive } \\
\text { emission }\end{array}$ & $\begin{array}{l}\text { Industrial } \\
\text { Pollution }\end{array}$ & $\begin{array}{l}\text { Tobacco } \\
\text { Smoking }\end{array}$ \\
\hline Dust storms & $\begin{array}{l}\text { Use of petroleum } \\
\text { coke and furnace } \\
\text { oil in Industries } \\
\text { which is the major } \\
\text { polluter }\end{array}$ & $\begin{array}{l}\text { Biological } \\
\text { Sources }\end{array}$ \\
\hline $\begin{array}{l}\text { Dust from } \\
\text { Construction }\end{array}$ & Burning of Cracker & \\
\hline
\end{tabular}

\section{Air Pollution Governance In Delhi}

Governance of air pollution is an extensive process, which has now been abruptly contested for more than two decades. Since there's a significantly visible interface between air pollution and public health, it has become the responsibility of governance to address it. Moreover, as per the Public Trust Doctrine, the government is the owner of the nature and resources of the country and it is the responsibility of the government to protect, prevent and sustain it from deterioration for citizens. 
Delhi is a union-territory commanded and controlled by a central government appointed Lieutenant Governor. It is a sub-state as well with its own elected representatives leading the state government legislature. The third level of governance in Delhi is made up of various local governments (municipalities) that operate at municipal areas and ward levels. Controlling an environmental issue of air pollution in such a governance system becomes a complex task. Here this study tries to bring out many theory and explanatory aspects of the governance debate, in the following subsections for a broad picture of which it has been structured as:

\section{Constitutional Framework}

2. Air Pollution Monitoring and Air Pollution Control Regimes Constitutional Framework $\varnothing$ Air (Prevention and Control) of Pollution Act, 1981

Ø Environmental Protection Act, 1986

$\varnothing$ National Environmental Appellate Authority Act, 1997

$\varnothing$ National Green Tribunal Act (NGT), 2010

$\varnothing \quad$ National Health Policy, 2017 Para Three (3.2)

Preventive and Promotive Health: "Reducing indoor and outdoor air pollution"; "Health Impact

Assessment" 15

Air Pollution Monitoring and Control Regimes

These are some of the engaged Constitutional bodies and Authorities who are in the Air Pollution Monitoring and Control work.

\section{Results and Discussion Past to Present: Air Pollution Governance in Delhi}

This section of paper brings out how the multi-level governance of Delhi has tried to control the risk of air pollution since 1980's and till now it continues. The government exercises the constitutional structure for the country changed with the Air (Prevention and Control of Pollution) Act in 1981, subsequently few notifications such as Notification for Nation Ambient Air Quality were issued by the Ministry of Environment, Forest \& Climate Change. Despite that there was no initiative taken of air pollution control in the Union Territory of Delhi, in that period of time.

By the time, population increased rapidly resulting with swift urbanization and industrialization, the city started to expand and many industries started to establish in the heart of the city.
The Supreme Court made amendments to the Environment (Protection) Act after hearing the writ petition filed by Environmentalist Lawyer M. C. Mehta on 7 th January 1998, While 1st setting up of EPCA under Section 3 of the act. The Act stated that The Conversion of Catalytic converters in engines, conversion of all public and commercial vehicles operating in Delhi into CNG fuel mode and relocation of hazardous industries were also mentioned in the decisions. City's air had deteriorated and also become the benchmark of the beginning of an era of Environment Jurisprudence for the country in that period. Many of the decisions were amended due to the writ petitions $(1985,1996)$ and initiatives taken by the Environmentalist lawyer M.C.Mehta. Regardless of all the decisions and orders gaps in view of the Court's decision into strong policy and taking rigorous action has been found in the long run.

\begin{tabular}{|c|c|c|}
\hline $\begin{array}{l}\text { Air Pollution } \\
\text { Authorities }\end{array}$ & $\begin{array}{c}\text { Air Pollution Control } \\
\text { Regimes }\end{array}$ & $\begin{array}{l}\text { Other Principal } \\
\text { Constitution bodies }\end{array}$ \\
\hline $\begin{array}{l}\text { - DPCC (Delhi Pollution } \\
\text { Control Committe. } \\
\text { - CPCB (Central } \\
\text { Pollution Control } \\
\text { Board) } \\
\text { - IMD (Indian } \\
\text { Meteorological } \\
\text { Control Board } \\
\text { - SAFAR (System of Air } \\
\text { Quality and Weather } \\
\text { Forecasting and } \\
\text { Research (SAFAR). } \\
\text { - Private organization } \\
\text { like skymet }\end{array}$ & $\begin{array}{l}\text { - Elected government } \\
\text { of NCT of Delhi: } \\
\text { Department of } \\
\text { Environment, } \\
\text { Department of } \\
\text { Health, Department } \\
\text { of Transport } \\
\text { - Central Pollution } \\
\text { Control Board, Delhi } \\
\text { Pollution Control } \\
\text { Committe. } \\
\text { - Municipal Authorities } \\
\text { - Environment Pollution } \\
\text { (Prevention \& Control } \\
\text { Authority) EPCA }\end{array}$ & $\begin{array}{l}\text { - Ministry of } \\
\text { Environment, Forest } \\
\text { and Climate Change } \\
\text { - Supreme Court } \\
\text { - Environment Apellate } \\
\text { Authority } \\
\text { - National Grene } \\
\text { Tribunal }\end{array}$ \\
\hline
\end{tabular}

Figure 3: A broad list of major contributors to the air pollution in Delhi

Taking the matter into action, The Environment Jurisprudence for coping up with Delhi's pollution in collaboration with the consecutive governments and authorities at various levels introduced different sets of policy plans. Taking the matter into actions, The Environment Jurisprudence for coping up with Delhi's pollution in collaboration with the consecutive governments and authorities at various level introduced different set of policy plans ; And comprehensive action plan 17 by Central Pollution Board, Clean Environment cess was put and initiatives like Were introduced to 'tackle' and 'manage' the risk of air pollution more than 'minimize' the risk with long term beneficial measures. Temporarily, The Air Quality has been steeping low each year over the last half decade or 
so. Policy Initiatives are mostly short term solutions for the main cause to control and reduce the levels of pollution. A Private member bill is also sought to be introduced in Parliament of India demanding Rights to Clean Air as a prerogative of Honorable Minister of Parliament Deepender Hooda.

\section{Vehicles Produce 10\% Of Delhi Air Pollution In Summer}

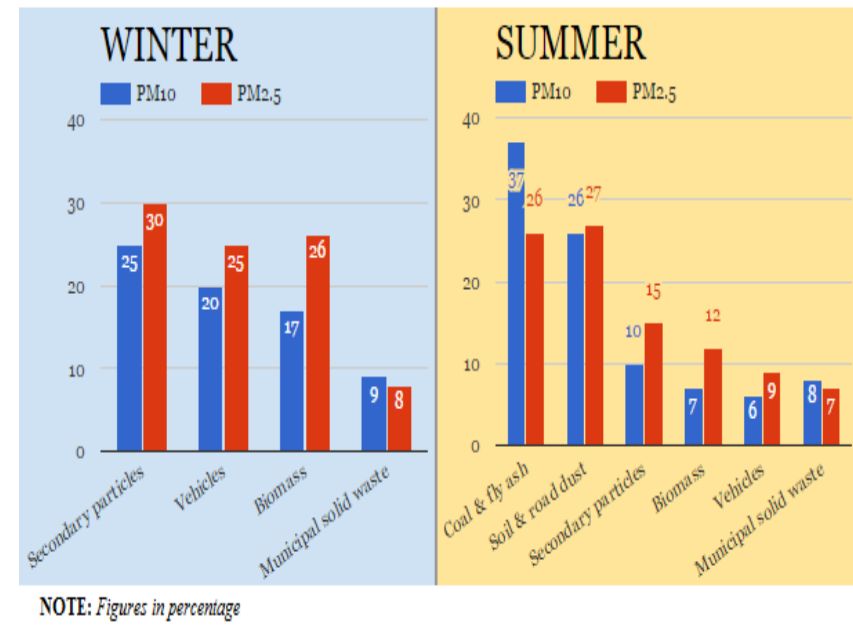

Figure 4: Showing Pollution in two major climates.

Also, many experiments were tried and tested such as Trail of Anti-Smog guns and proposals for Anti- pollution Towers. MOEF\&CC and Delhi Government had led a Clean Air Campaign in Delhi initiated for a week in February 2018.

Therefore, the level of air quality now remains poor for most of the year which can be confirmed well from the CPCB's data. Air pollution has turned hazardous and putting up a mask to aim preventive action for better health cannot be the actual solution. Delhi has been declared a Public health emergency on various occasions, various health studies have proven it as well. Strict and Proper Policy guidelines need to be introduced in order to truly manage the ever high risk of Air Pollution in Delhi and its neighboring regions and build a safer and sound environment for its people.

\section{Conflict of Interest: none}

\section{vi. CONCLUSION}

The National capital Territory of Delhi is badly facing the danger of Air pollution and its resultant impacts. From the above mentioned section of this paper, it's very clear that the air pollution governing body in Delhi is a multi-layered and multi-institutional procedure. The network of government cognition imposes restriction in governance of air pollution in Delhi as it hinder the intervention of actions within the inter-departmental and inter-agency system of working. Much has been done and much awaits in this drive. Right to life and right to a healthy environment are being profaned by increasing air pollution levels in the city. Over the years the diseases are increasing day by day. Now, it has become important to control the air pollution and also to make Delhi's air quality living. Air pollution governance in Delhi is an on-going issue of fear and hence its governance would also be a never-ending procedure till the time air quality reaches a lengthy period of satisfactory levels. As Air has become a Public health concern, governance has to keep the pace with the increasing health risk, so that the situation will be under control.

\section{REFERENCES}

[1] Véron R. Remaking urban environments: the political ecology of air pollution in Delhi. Environment and Planning 2006; 38(11): 2093-109.

[2] Jeremy H. Air Pollution kills 7 million people a year, WHO reports. Bloomberg, 2018. 3. United Nations. Sustainable development goals. Department of Economic and Social Affairs, 2015.

[3] Central Pollution Control Board. Non-attainment cities with respect to Ambient Air Quality India (2011-15). 5. Ibid. 6. Health Effects Institute. State of Global Air, 2017. Special Report.

[4] The Wire Staff. Delhi Air Pollution a 'Public Health Emergency', Says IMA; Kejriwal suggests Shutting Schools. The Wire, 7th November 2017. Available from:

[5] https://thewire.in/environment/delhi-air-pollutionpubli c-health-emergency-says-ima-kejriwal-suggestsshut ting-schools-days. 8. Express Web Desk. IMA declares 'public health emergency state' in Delhi, wants Half Marathon cancelled. The Indian Express. 7th November 2017; Available from https://indianexpress.com/article/india/

[6] ima-declares-public-health-emergency-state-in-delhi wants-half-marathon-cancelled-492626/ 9. Gupta A. India junks an environmental report, once again.

[7] CGTN. Available from: https://news.cgtn. com/news/3d3d514e33597a4d79457a6333566d54/

share_p.html WHO statement. 10. Cropper LM, Simon N, Alberini A, et al. The health benefits of air pollution control in Delhi. American Journal of Agricultural Economics 1997; 79: 1625-9. 11. WHO. Air Quality guidelines for particulate matter, ozone, nitrogen dioxide and sulphur dioxide. WHO Press Geneva, 2005. Available from: http://www.who.

int/phe/health_topics/outdoorair/outdoorair_aqg/ en/.

[8] Dr. Subhadra Rajpoot, "Current Technologies for Waste Water Treatment in Chemical Industries in India", International Journal for Multidisciplinary Educational Research, Vol. 08, Issue 05, May 2019, pp.-12-15.

[9] Dr. Subhadra Rajpoot, "Renewableenergy And Its Future Potentialin India"', International Journal for Modern Trends in Science and Technology, Vol. 05, Issue 05, May 2019, pp.-12-15.

[10] Dr. Subhadra Rajpoot, "A Review on ways to Manage Biomedical Waste at Different Locations in Faizabad", International Journal for Modern Trends in Science and Technology, Vol. 06, Issue 01, January 2020, pp.-33-36. 
[11] 12. Central Pollution Control Board. National Ambient Air Quality Monitoring Programme Data, 2016. Available from: www.cpcb.nic.in. Accessed on: June 2018.k 13. PTI. Dust storm in West Asia precipitated Delhi smog crisis: SAFAR. Times of India, 16th November, 2017. Available from: https://timesofindia.indiatimes.com/

[12] city/delhi/dust-storm-in-west-asia-precipitated-delhi smog-crisis-safar/articleshow/61674380.cms. 14. Ibid. 15. Legislative Service India. Notion of Doctrine of Public Trust in India. Available from: http://www. legalservicesindia.com/article/1429/Notion-ofDoctrin e-of-Public-Trust-In-India.html. 16. Ministry of Health and Child Welfare. National Health Policy, 2017.

[13] Dr.Subhadra Rajpoot, Kabom Lego, Effect Of Particulate Matter (Pm) On Climate, Plants, Human Health And Ecosystem, International Journal Of Scientific Research : Volume-7 | Issue-5 | May-2018

[14] Available from: http://cdsco.nic.in/ writereaddata/National-Health-Policy.pdf. 17. Environment Pollution Control Authority. Graded response action plan. Available from: http://www. epca.org.in/. Accessed on: August, 2018. 18.

[15] Dr. Subhadra Rajpoot USE OF BIOFUELS TO CONTROL POLLUTION IN AUTOMOBILES International Journal of Engineering Research and General Science Volume 4, Issue 4, July-August, 2016 ISSN 2091-2730.

[16] Comprehensive action plan for air pollution control in Delhi \& NCR. Available from: http://www.epca.org. in/EPCA-Report

[17] 1999-1917/Final-EPCA-Report-71CAP-for-Delhi-NC R.pdf. 19. Express Web Desk. What is an Anti-smog gun? The Indian Express. 20th December, 2017.

[18] Available from: https:// indianexpress.com/article/what-is/what-is-anti-smog gun/. 20. Ghosal A. Delhi government pins clean air hopes on anti-pollution towers. The Indian Express. 20th February, 2018. Available from: https://indianexpress.com/

[19] article/cities/delhi/delhi-govt-pins-clean-air-hopes On hopes

[20] on-anti-pollution-towers-5070690/. 21. Ghosal A. Delhi government, MoEF jointly launched 'Clean Air Campaign'. The Indian Express. 11th February 2018. Available from: https://indianexpress.com/article/

[21] cities/delhi/delhi-government-moef-jointly-launch clean-air-campaign-5058639/. 22. Ghosal A. Delhi pollution: Deepender Hooda plans to bring in right to clean air bill, writes to PM. The Indian Express. 13th November 2017. Available from: https:// indianexpress.com/article/cities/delhi/delhi-pollution deepender-hooda-plans-to-bring-in-right-to-clean-air bill-writes-to-pm-4934731/. 